\title{
INTEGRATED APPROACH TO TEACHING ESP AT ENGINEERING UNIVERSITY
}

\author{
Olha Chaikovska $^{1}$, Valentyna Spivachuk ${ }^{2}$, Iryna Humeniuk ${ }^{1}$, Vasyl Holinei ${ }^{1}$ \\ ${ }^{1}$ State Agrarian and Engineering University in Podillia, Ukraine; \\ ${ }^{2}$ Khmelnytskyi National University, Ukraine \\ olgachaikovskaya@ukr.net, spivachuk_vo@ukr.net, irynahumenyuk79@gmail.com, \\ holyney@gmail.com
}

\begin{abstract}
Agriculture is almost the only industry in Ukraine that shows its stable growth despite the complicated social and economic conditions. It provides plenty of job positions that require a good command of English. The results of EfU baseline study in Ukrainian universities showed that ESP courses do not prepare the students to communicate at the workplace and do not provide mastering specific vocabulary related to their future job. The research deals with teaching profession-based topics from the "Agricultural machinery" course in a foreign language in line with engineering students' notion about the necessity of English discipline-specific knowledge. The article informs about the results of the students' presentations at the conference as progress in their professional knowledge, based on the integrated curriculum. Several studies have reported on ESP teaching with the technical university students according to CLIL and EMI methodology, however, an integrated approach to ESP teaching remains to be accomplished. The paper aims to examine the integrated approach at the content level through the integration of the discipline "Agricultural machines" into ESP course and at the methodological level through well-built and effective profession-based learning strategies. The study used pre-and post- questionnaire design that resulted in students' engineering conference presentations. The recommendations on discipline-specific content and activities in the integrated ESP course are given. The study reveals the benefits of using engineering profession-based tasks for successful student performance.
\end{abstract}

Keywords: integrated approach, agricultural machinery, engineering education, ESP syllabus, profession-based.

\section{Introduction}

In the 2020 English Proficiency Index Ukraine was ranked the $44^{\text {th }}$ of 100 countries and the $30^{\text {th }}$ of 34 European countries [1]. The government recognizes the importance of English in accessing and expanding human educational and professional opportunities. Students of technical universities in our country show poor progress in the context of foreign language learning. It is explained, first of all, by the fact that teaching ESP (English for specific purposes) usually poses a lot more challenges in comparison with teaching EGP (English for general purposes) [2].

Secondly, engineering students study ESP for a short period of time. For example, foreign language study for Agricultural Engineering major at the State Agrarian and Engineering University in Podilia takes 4 semesters ( 2 semesters for EGP and 2 semesters for ESP). But what is important, the students have a 2-year gap, when they do not have foreign language classes. As a result, the engineering graduates are not ready to meet industry's expectations in relation to foreign language context. Borg (2019) in his summary on EfU (English for Universities Project) emphasized the need for improving ESP study skills and developing a new ESP syllabus for Ukrainian universities [3].

The changes to the ESP syllabus suggest content that is professionally relevant and based on the needs analysis rather than general, including input from subject lecturers and introducing team-teaching between ESP and EMI staff.

ESP, CLIL (Content and Language Integrated Learning) and EMI (English as a Medium of Instruction) are believed to help in preparing a qualified engineering workforce for the world labour market [4-8]. Since CLIL and EMI are not in the focus of the present study according to several reasons, such as the absence of foreign students and lack of subject teachers ready to teach in English, we will investigate an integrated approach to ESP teaching with the engineering students, which is more appropriate in Ukrainian universities located within a rural area.

In the history of ESP teaching, the focus has always been on ESP course design (whether it is careerbased and meets the engineering students' needs). Overseas experience in ESP teaching with engineering students shows that English courses were not discipline-specific and forward-looking introduction of profession-based terminology content in ESP classroom, they suggest a high level of ESP and major subject correlation [5]. ESP in engineering university does not prepare students for 
English communication at the workplace [6], the majority of the learners had a low level of proficiency in the target language $[7 ; 8]$ but want to master specific vocabularies related to their future job [9].

Some scientists consider teaching in an integrated context a big challenge, because the content should be absorbed through the so-called "filter" of a foreign language, which implies the concentration of the learner simultaneously on both the content and the form [10]. To obtain more in-depth information about profession-based ESP teaching we provided an overview of sources concerning the investigated research problem. The synthesis of the English language and the discipline "Open cast mining" at the National Mineral Resources University provided developing skills in technical translation, the ability to review career-based literature, communicate and exchange information in a professional context; at the informative level the students should learn the basics of mining operations, operating principles and parts of mining equipment and using vocabulary in a professional context [11]. Few researchers have addressed teaching of mathematics, sketch geometry in pedagogical university [10], engineering graphs, theoretical mechanics, theory of mechanics and machines, resistance of materials [12], database course [5] according to CLIL methodology, when teaching mathematics and engineering disciplines was carried out in English. The researchers have addressed the issues of ESP course based on CLIL technology, its learning objectives and syllabus design. Although an integrated approach to ESP learning is promising, it suffers from a lack of system development in conceptual foundations and methodological framework.

\section{Materials and methods}

The experiment was conducted from 2018 to 2020 among the second-year students $(n=44)$ of the Engineering Department at the State Agrarian and Engineering University in Podilia. The experiment involved open and long-term participant observations, pre- and post- experiment questionnaires and final testing in the form of an interdisciplinary engineering conference. In this research, the responses to the questionnaires from agricultural engineering students were used to obtain quick and accurate views of the respondents' language needs and expectations in an academic context. This information helped the researchers determine the students' difficulties and their needs regarding their English language skills in particular. Factual, scaled, and open-ended questions were used in the questionnaire. The survey questionnaire was carried out after ESP month-learning process and performed using Google Form.

\section{Results and discussion}

Agricultural engineering students speak Ukrainian as their native language, while English is a foreign language used primarily in EFL classroom, English language clubs, courses and in socializing with their overseas friends in different social media. The educational and professional program in "Agricultural Engineering" is the framework for the ESP syllabus [13]. It is designed in collaboration with stakeholders and subject teachers. ESP syllabus, teaching materials and resources, learning methods and techniques, lesson plans are focused on achieving the objectives of the educational and professional program. The analysis of the learning objectives from both disciplines (English and Agricultural machines) makes it possible to confirm that agricultural engineers must describe the structure, functions of agricultural machinery, technological processes of production, storage, processing and transportation of agricultural products, explain the operational principles of agricultural machinery, determine advantages and disadvantages of a certain type of agricultural machinery and equipment, substantiate machine working bodies under the soil and climatic conditions and characteristics of agricultural materials in a foreign language.

After studying some topics of general professional content: Measurements, Analyzing quantities and Describing change, Agricultural engineering in Ukraine and abroad, the questionnaire was carried out. Figure 1 shows that the main reason for Agricultural engineering students to study English is the opportunity to find a job abroad (34\%). $27 \%$ of engineering students master ESP to get a job in Ukraine. Unfortunately, only $12 \%$ of the respondents plan to get a Master degree and pass the general exam in English. Based on the result, it is seen that the majority of respondents realize the importance of foreign language fluency for their job and career development. 


\section{I will need English to}

apply for a job abroad
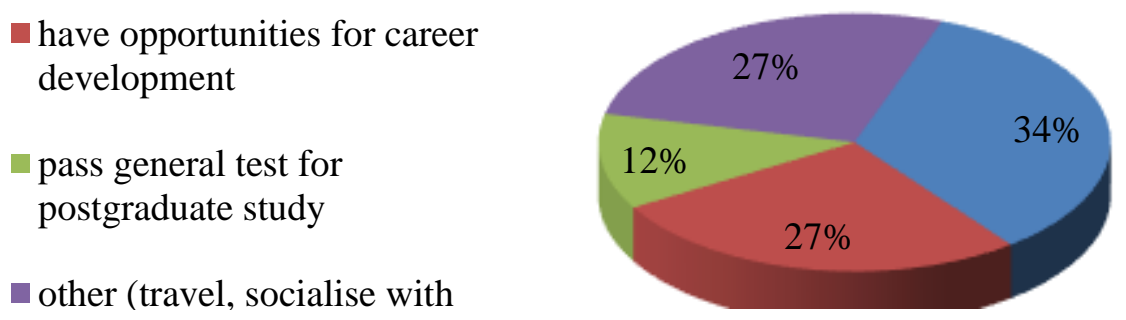

Fig. 1. Percentage result of question 1 (Why do you need to study ESP?)

In question 2 agricultural engineering students were asked to indicate the extent to which they agreed that English material should be suitable for their major. Almost all respondents (80\%) commented that English material should be career-based.

\section{Question 2}

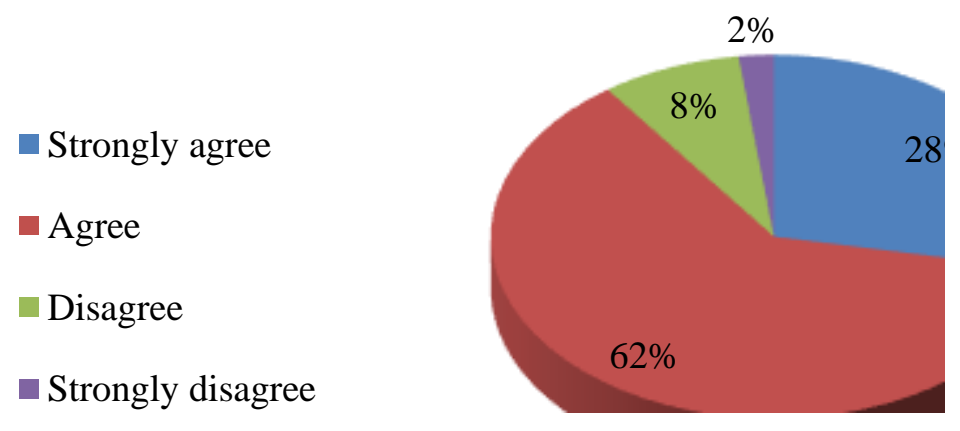

Fig. 2. Percentage result of question 2

In response to question 3 (What topics of your major do you want to be more emphasized in ESP class?) over half replied that they would like to learn more about foreign agricultural machinery. It is explained, to our mind, by the fact that during a month of ESP study we covered the topic "Agricultural Engineering in Ukraine" and came to a conclusion that Ukrainian farmers prefer to purchase foreign grain combines and tractors. $11 \%$ of those surveyed reported that they would like to learn agricultural service and repair. We believe that agricultural engineering students remembered the information that approximately $40 \%$ of tractors are 15-25 years old and some agricultural enterprises buy second-hand machinery from Europe. Remarkably, but $15 \%$ of students showed interest in electric machines and drives.

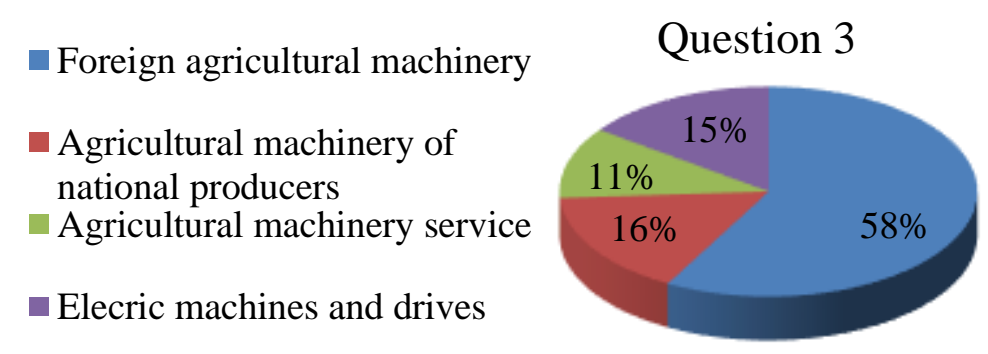

Fig. 3. Percentage result of question 3 
Responding the question 4 (What foreign language skills would you like to improve?) $47 \%$ of students understood the importance of speaking skills (47\%), vocabulary (17\%) and listening (19\%) for their foreign language learning.

\section{Question 4}

- Listening
- Reading
- Speaking
- Writing
_ . .

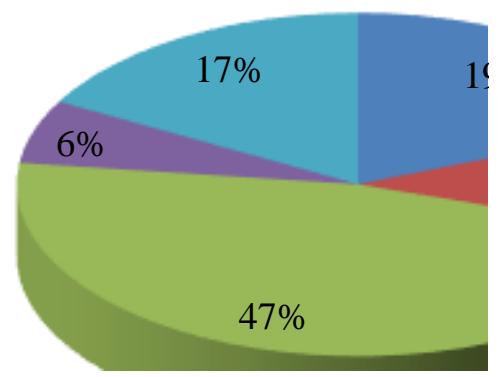

Fig. 4. Percentage result of question 4

The $5^{\text {th }}$ question of the survey was used to scale the importance and interest in certain ESP classroom activities from the most needed (1) to less needed (10).

\section{Question 5}

- Describing an object

- Comparing and contrasting things

Describing processes and procedures

- Reporting information from other sources

Makino nresentations or nroiects

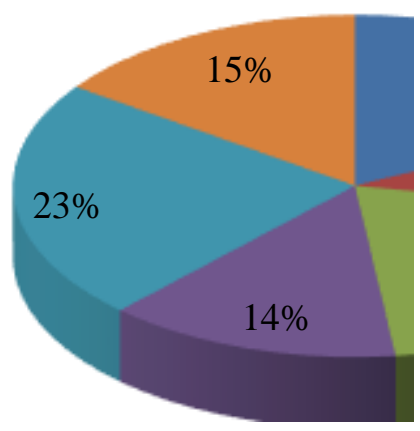

\section{Fig. 5. Percentage result of question 5}

We considered all respondents' answers to the questionnaire in our further integrated ESP course. In collaboration with the subject teacher, we have chosen the topics that are studied parallel in both disciplines: Soil classification and composition; Types of soil cultivation; Planting and cultivating equipment, Harvest Equipment; Tractors. To provide enough explanation, add critical thinking tasks and increase students' motivation we designed new agricultural engineering-based exercises and experimental tasks. Agricultural engineering students liked experiments on identifying soil composition. The experiment called "bottle" involves knowledge of mathematics and physics. We put some soil into the bottle, filled it with water and shook it up. As a result, we got different layers of soil components depending on their weight. Exploring tractors, we developed a series of exercises relevant to the topic.

1. What oil temperature is necessary for the diesel engine operation? $\left(50-65^{\circ} ; 70-85^{\circ} ; 90-95^{\circ} ; 100\right.$ $105^{\circ}$ ).

2. What figure shows the layout of the placement of attachable machines and devices for the tractor?
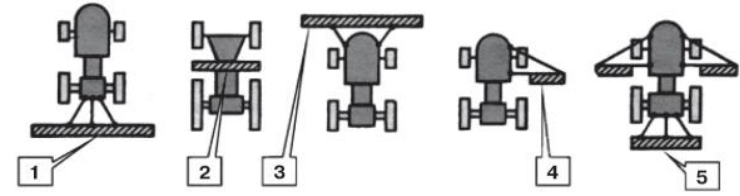

Fig. 6. Layout of placement of attachable machines and devices for the tractor 
3. Imagine that you work as an agricultural engineer at an agricultural enterprise. Describe what agrotechnical requirements are for ploughing according to the given parameters (Tractor: MTZ-80, T-25, T-40; Plough: Mounted plough-3-35, 5-35, 6-35; Area: 4 ha).

To evaluate agricultural engineering students' performance in the integrated ESP course we organized an engineering students' conference. The participants were required to choose from the topics studied during the ESP course and to prepare oral presentations. The presentations were judged for the content (knowledge of the material, terminology), language, organization (introduction, division of themes and conclusion), clarity of artwork (charts, graphs, slides) by ESP and subject teachers. As far as language was concerned, we examined grammar accuracy, appropriate usage of terminology, pronunciation. Students were given 10 minutes for their presentation including questions from the judges. The total score for oral presentation was 40. Table 1 shows the distribution of scores for oral presentation.

Table 1

Oral Presentation: Scoring Guide

\begin{tabular}{|l|c|c|c|}
\hline $\begin{array}{c}\text { Oral presentation grading } \\
\text { criteria }\end{array}$ & Exceeds expectations & Meets expectations & $\begin{array}{c}\text { Does not meet } \\
\text { expectations }\end{array}$ \\
\hline Content/15 points & $12-15$ & $6-12$ & $0-6$ \\
\hline Language/15 points & $12-15$ & $6-12$ & $0-6$ \\
\hline Organization/5 points & $4-5$ & $2-3$ & $0-2$ \\
\hline Clarity of artwork/5 points & $4-5$ & $2-3$ & $0-2$ \\
\hline
\end{tabular}

The most important criteria for our experiment were the engineering content and foreign language, which were graded 15 points accordingly.

Participants' scores according to expectations

Table 2

\begin{tabular}{|l|c|c|c|}
\hline \multirow{2}{*}{$\begin{array}{c}\text { Oral Presentation Grading } \\
\text { Criteria }\end{array}$} & Exceeds expectations & Meets expectations & $\begin{array}{c}\text { Does not meet } \\
\text { expectations }\end{array}$ \\
\cline { 2 - 4 } & Participants $(n=44)$ & Participants $(n=44)$ & $\begin{array}{c}\text { Participants } \\
(n=44)\end{array}$ \\
\hline Content & 8 & 29 & 7 \\
\hline Language & 6 & 34 & 4 \\
\hline Structure of the presentation & 2 & 23 & 19 \\
\hline Clarity of artwork & 20 & 22 & 2 \\
\hline
\end{tabular}

The data analysis indicated that most engineering students' oral presentations met the expectations in the content and language context. Only 15\% (Content) and 9\% (Language) of respondents failed to meet the expectations. The number of students who had low scores according to the language criterion is not significant, while the percentage of participants who showed bad performance in the engineering content is rather high. It is explained, to our point of view, by the fact that these students perform at a low level within all subjects. To reduce such achievement gaps subject and ESP teachers should offer extra help, such as after-class activities. The same considers the structure of oral presentation. Almost all engineering students' presentations had well-designed slides, captions on pictures and graphs, however, the organization of the presentation body should be emphasized in the ESP classroom.

To examine the students' attitude to the ESP lectures the authors made the same questionnaire after the lectures have been delivered. The results of post-experiment questionnaire revealed that the key factor for foreign language learning was still the desire to apply for a job abroad (question 1). More students strongly agreed that the topics they studied should coincide with the themes of their specialization in question 2 (43\% in comparison to $28 \%$ in the pre-experiment questionnaire). The most attractive topics for engineering students remained "Foreign agricultural machinery and equipment" (question 3). However, interest in "Agricultural machinery service and repair" increased almost in 2 times (from $11 \%$ to $27 \%$ ). To our point of view, it is explained by the difficulties the students faced communicating on machinery disorder. According to the students' after course experience speaking and vocabulary acquisition are still the most in-demand. After participating in the engineering conference, 
the respondents realized the importance of foreign language communication in professional context and the results of their experience were reflected in answers to question 5. The most needed in the ESP classroom activities were developing skills in oral presentations and projects (34\% in contrast to $23 \%$ in questionnaire 1) and describing agricultural machinery processes and procedures (20\% and $31 \%$ accordingly). To learn about the students' impression of their progress in their professional knowledge we added an open-ended question: How the integrated ESP course influenced your professional knowledge? The three most frequent answers were as follows: I can use language appropriately in jobrelated tasks, the course focuses on what I need and the course helps me develop awareness of my future concern.

\section{Conclusions}

1. The results of the survey revealed that implementation of integrated approach to ESP teaching can improve the students' overall academic performance in engineering university. ESP syllabus in engineering university must be designed following an educational and professional programme, recommendations of subject teachers and engineering students' needs and expectations in the context of their future job.

2. The content of the integrated ESP course should include materials on foreign agricultural machinery and equipment, agricultural machinery service and repair and a range of activities that aim to provide developing speaking skills and acquiring engineering vocabulary.

3. The findings showed that the use of discipline-specific materials and profession-based tasks concerning the "Agricultural machinery" course in ESP university classroom benefits students' progress, first of all, in ESP communication and in career-based vocabulary acquisition.

\section{References}

[1] EF EPI 2020 - EF English Proficiency Index. (In English). [online] [12.11.2020]. Available at: https://www.ef.com/wwen/epi/.

[2] Fălăuş A. The current challenges of teaching ESP. IOP Conference Series: Materials Science and Engineering, 200, 2017. 012059. (In English). [online] [10.03.2020.] Available at: https://iopscience.iop.org/article/10.1088/1757-899X/200/1/012059

[3] Borg S. The Impact of the English for Universities Project on ESP and EMI in Ukrainian Higher Education: Final Report. 2019. (In English). [online] [10.04.2020.] Available at: https://www.britishcouncil.org.ua/sites/default/files/efu_impact_report_.pdf

[4] Vinke A. A. English as the medium of instruction in Dutch engineering education, Technische Universiteit Delft, 1995. (In English). [online] [10.04.2020.] Available at: http://resolver.tudelft.nl/uuid:491b55f9-fbf9-4650-a44d-acb9af8412a8

[5] Попова Н. В., Коган М. С., Вдовина Е. К. Предметно-языковое интегрированное обучение (clil) как методология актуализации междисциплинарных связей в техническом вузе. Вестник Тамбовского университета. Серия: Гуманитарные науки, 23 (3 (173)), 2018. С. 2942. (In Russian).

[6] Dahbi M. Towards an ESP Course for Engineering Students in Vocational Schools in Morocco: the Case of the National School of Applied Sciences. ASELS Annual Conference: Proceedings, Mohammed V University of Rabat, Morocco, 2016. pp. 72-81.

[7] Hossain J. ESP Needs Analysis for Engineering Students: A Learner Centered Approach. Journal of Presidency University, 2(2), 2013. pp. 16-26.

[8] Kim H.H. Needs Analysis for English for Specific Purpose course Development for Engineering Students in Korea, International Journal of Multimedia and Ubiquitous Engineering, 8 (6), 2013. pp. 279-288.

[9] Michalache R. Motivation vs. need of ESP of engineering students, Journal of international social research, 8(36), 2015. pp. 968-979.

[10] Салехова Л.Л. Дидактическая модель билингвального обучения математике в высшей педагогической школе (Didactic model of bilingual mathematics training at higher education school). Dissertation abstract by the Doctor of Pedagogical Sciences, Kazan, 2008. 41 p. (In Russian). 
[11] Иванова М. А., Кузнецова Е. В. Технология обучения иностранным языкам на основе междисциплинарного подхода (Technology for learning foreign languages on the basis of an interdisciplinary approach). Society: Sociology, Psychology, Pedagogy, 2, 2016. pp. 160-162. (In Russian).

[12] Крылов Э.Г. Билингвальное обучение инженерным дисциплинам и иностранному языку в вузе (Bilingual training in engineering and foreign language at the university). Moscow, Izhevsk: Institute of Computer Research, 2015. 148 p. (In Russian).

[13] Educational and professional curriculum. Agricultural engineering [online] [05.12.2020]. Available at: https://pdatu.edu.ua/images/navchalna-robota/opp/opp-b-itf-5-pmoav-2.pdf 